\title{
Street Children Religious Education Using an Interactional Education Approach
}

\author{
Machfudzil Asror $^{(1)}$, Achmad Wahyudi ${ }^{(2)}$ \\ Universitas Nahdlatul Ulama Sidoarjo, Indonesia \\ E-mail: ${ }^{(1)}$ machfudzil.asror1985@gmail.com
}

Received: 15 December 2020; Revised: 22 April 2021; Accepted: 5 May 2021

\begin{abstract}
This research is a field research which the required data is extracted from the field. This research used descriptive qualitative method. The subjects of this research are street children in Sidoarjo regency and related agencies such as the Social and Labor Office, the Education Office and the Ministry of Religion of Sidoarjo Regency. Street children who are the targets of this study are children aged 18 years and under, both boys and girls who live on the streets. The object of this research is religious education of street children in Sidoarjo regency. The data that will be explored in this research are those related to religious education in street children in Sidoarjo district which includes: First, the characteristics of street children in Sidoarjo regency. Second, the background to be street children. Third, the form of religious education carried out in the street children's community. Fourth, institutions involved in the religious education process of street children. Fifth, religious practices carried out by street children. Sixth, obstacles in implementing religious education in street children communities. The data collected in this research were collected through the interview, observation and documentation techniques. After the data has been collected using these various techniques, the data obtained is collected and described in a data matrix. The data in this study were analyzed using interactive model analysis techniques.
\end{abstract}

Keywords: religious education; Street children; interactional education;

\section{INTRODUCTION}

As social The existence of street children is commonly seen in big cities in Indonesia. Children are a gift from God and a mandate that is inherent in human dignity and must be upheld. Children's rights are part of human rights as stated in the 1945 Constitution, Law Number 39 of 1999 concerning Human Rights, and Presidential Decree Number 36 of 1990 concerning the ratification of the Convention of the Right of the Child (Anwar, C., et al, 2018).

As acknowledged by the State of Indonesia, that in general, there are 10 children's rights referred to in the $1989 \mathrm{UN}$ Convention on the Rights of the Child (Coccia, M., 2014), namely: 1.Right to Play. 2. Right to education. 3. Right to protection. 4. Right to Identity. 5. Right to obtain Nationality status. 6. Right to Food. 7. Right to get access to health. 8. Right to recreat ion. 9. Right to Equality, and 10. Right to have a role in Development.

In order to anticipate the progress of the times and the demands of society in the field of public order and public order, to create an orderly and peaceful Sidoarjo Regency, it is necessary to replace Sidoarjo Regency Regional Regulation Number 5 of 2007 concerning the Implementation of Peace and Public Order which is 
felt inappropriate to the situation. Therefore, the Sidoarjo Regency Regional Regulation Number 10 of 2013 concerning the Implementation of Public Order and Public Peace was issued. The scope of public order and public order includes: 1) orderly roads, green lanes, sidewalks, parks and other public facilities; 2) orderly rivers, channels, ponds; 3 ) orderly environment; 4) orderly place and certain business; 5) orderly building; 6) social order; 7) orderly health; 8) orderly places of entertainment and crowds.

Based on Evans, C. (2008), from the eight existing scopes, researchers tried to find out, dig up data and analyze problems related to social order. The social order problem in Sidoarjo is the emergence of homeless, namely people with social welfare problems including homeless people, beggars, and street singers whose daily activities are looking for income or begging at road junctions and traffic lights.

In collecting the data, the researcher finds some research partners who also focus on caring the street children. They are colleagues of SSC (Save Street Child), a community movement that actualizes care for street and marginalized children (Huda, M. et al, 2017). This community has been formed since May 23, 2011 in Jakarta independently. In line with the existence of the Save Street Child community movement, this community eventually expanded in each region, so that it was able to make it a networking community. The decentralization of this movement made each region fully autonomous to carry out concrete activities. Now, the Save Street Child community has expanded to 18 cities, they are; Jakarta, Surabaya, Makassar, Medan, Bandung, Yogyakarta, Depok, Manado, Padang, Blitar, Malang, Semarang, Sidoarjo and so on.

Sidoarjo is one of the districts with a large population and fairly good industrial output in the Indonesian economy which is adjacent to the metropolis of Surabaya where there are strata of society that require special attention including marginalized children. Seeing the social conditions that occurred, Save Street Child Sidoarjo was established on May 24, 2015 with most of the activists being the young people of Sidoarjo Regency, one of them is Dwi Prasetyo (kak Pras) who cares about the surrounding social conditions and is expected to have great ideas to care about their environment. Save Street Child of Sidoarjo marked by the autonomous and independent creation of the Save Street Child Sidoarjo community bureaucracy which is fortified by four youth people in Sidoarjo who have big spirit and struggle. Now, there have been more than 100 members who have actively and passively participated in implementing the program of Save Street Child of Sidoarjo. The basic purpose of Save Street Child of Sidoarjo was formed based on the spirit of caring for minorities who are packaged in real action. Besides spreading awareness and enthusiasm for sharing, this community is also a forum for information about matters relating to street and marginalized children in Sidoarjo.

\section{MATERIALS AND METHODS}

Religious Education in this case means as the Islamic Education. Islamic education itself can be understood in several perspectives namely: 1) Education according to Islam, or education based on Islam, and or an Islamic education system, namely education that is understood and developed and compiled from the teachings and fundamental values contained in its basic sources, namely Al-Quran and As-Sunah. Here, Islamic education can take the form of educational ideas and theories that are self-based or built and developed from these basic sources. 2) Islamic education or Islamic religious education, namely an effort to educate Islam or Islamic teachings and values, so that they become a person's way of life. In this case, it can take the form of: (1) all activities that a person does to assist a person or group of students in instilling and or developing Islamic teachings and their values to 
serve as a view of their life, which is manifested in an attitude of life and developed in their daily life skills; (2) all phenomena or events of encounter between two or more persons whose impact is appear and the development of Islamic teachings and values on one or more parties. 3) Education in Islam, or the process and practice of education that took place and developed in the history of Muslims. In the sense of e process of growth and development of Islam and its people, both Islam as a religion, teaching as well as a cultural and civilization system, since the time of the Prophet Muhammad. Until now. In this sense it can be understood that Islamic education is a process of civilizing and inheriting the teachings of religion, culture and civilization of Muslims from generation to generation throughout its history.

According to (Knauth, T., \& Vieregge, D., 2020), street children are children who mostly spend their time making a living or roaming the streets or other public places. Street children can also be referred to as social disabilities, which means that people with social welfare problems include homeless people, beggars and street singers. The naming of social disabilities is in accordance with the Sidoarjo Regency Regional Regulation Number 10 of 2013 concerning the Implementation of Public Order and Public Peace (Perda Kab. Sidoarjo No.10 Th. 2013)

There are several kinds of educational theories that are widely discussed by educational experts and are considered to underlie the implementation of education, namely classical education, personal education, interactional education and educational technology. Classical education or classical education can be seen as the oldest educational concept. The concept of education is based on the assumption that all cultural heritage, namely knowledge, ideas, or values have been discovered by previous thinkers. Education functions to maintain, preserve, and pass all these cultural heritage to the next gener- ation. Teachers or educators don't need to bother looking for and creating new knowledge, concepts and values, because everything is available, just master it and teach it to children. Personal education prioritizes the role of students. The concept of education is based on the basic assumption that, since birth, children have the potential, both the potential to think, act, solve problems, as well as learn and develop on their own. Education starts from the needs and interests of students. Students become the subject of education, it is he who occupies the main place in education. Educators occupy the second position, no longer as conveyors of information or as models and experts in scientific disciplines. He functions more as a psychologist who understands all the needs and problems of students.

Another educational theory is interactional education, the concept of this education is based on human thinking as a social being. In his life, human always need others. They always live together, interact each other and work together. Because of this life together and cooperation, they can live, develop, and are able to provide their needs and solve their problems. The curriculum model from interactional education theory is called the social reconstruction curriculum. The social reconstruction curriculum is a curriculum that focuses more on the problems it faces in society. This curriculum is sourced from the interactional education stream. According to some people education is not an independent effort, but a joint activity, interaction, cooperation. Cooperation or interaction occurs not only between students and teachers, but also between student and student, students and people in their environment and with other learning sources. Through this interaction and cooperation students try to solve the problems they face in society towards the formation of a better society (Parker, L., 2017).

This research is a field research where the data are collected from the field. This research used descriptive qualitative method. The research subjects are street children in Sidoarjo regency, related agencies such as the Social and Labor Of- 
fice, the Education Office and the Ministry of Religion of Sidoarjo Regency. Street children who are the targets of this research are children who aged 18 years and under, both boys and girls who live on the streets. The object of this research is religious education in street children in Sidoarjo.

The data that will be gained in this research are those related to religious education in street children in Sidoarjo which includes: first, the characteristics of street children in Sidoarjo. Second, the background to be street children. Third, the form of religious education carried out in the street children community. Fourth, institutions involved in the religious education process of street children. Fifth, religious activities carried out by street children. Sixth, obstacles in implementing religious education of street children communities.

The data collected in this study were collected through interview, observation and documentation techniques. After the data has been collected using these various techniques, the data obtained is collected and described in a data matrix. The data in this research were analyzed using interactive model. Yusuf, M., \& Sterkens, C. J. A. (2015) state that in interactive model analysis consists of three flow of activities that occur, namely: data reduction, data presentation, and conclusion / verification. Data reduction is the process of selecting and sorting data from the results of written records in the field. Presentation of data is the presentation of research results in narrative form. Meanwhile, verification is drawing conclusions based on data in the field, then drawing conclusions from observations and documents that are continuously processed.

\section{RESULT AND DISCUSSION}

In fact, the reseacher find that street children who usually do activities in Sidoarjo are come from poor rural families in Sidoarjo. They become urban poor urban residents. Their hope is to go to the city so that their daily needs are fulfilled by begging, busking at traffic lights and other public places in the city. Most of the interactions of children are spent on the streets so that their school and play periods are neglected, because they are child laborers.

The street children in Sidoarjo are come from Sidoarjo District, Buduran District and Candi District. From the City of Sidoarjo District, including Lemah Putro Village, Magersari Village and Sidoklumpuk Village. From Buduran District, among them are Pagerwojo Village, Buduran Village and Siwalan Panji Village. From Candi District, they are Larangan Village, Sepande Village and Tenggulunan Village.

The characteristics of street children in the Sidoarjo are they more concerned to earn money than to get education, especially religious education. Their religious teaching guidance is usually every Saturday and Sunday afternoon by volunteer from SSC Sidoarjo. Their obstacles in implementing Islamic teachings are the situation and environment that are less supportive and the lack of religious teaching staff in their community who want to become the volunteers.

\section{CONCLUSION}

Through religious education based on interactional education theory, the street children can learn Islam by the theory and direct practice in their activities on the streets and public places, for example: reciting the holy Qur'an and rowatib prayer, habituation of manners in speech (permission and thanking expressions) every time you interact with everyone, throw garbage in its place and so on.

\section{REFERENCES}

Anwar, C., Saregar, A., Hasanah, U., \& Widayanti, W. (2018). The effectiveness of islamic religious education in the universities: The effects on the students' characters in the era of industry 4.0. Tadris: Jurnal Keguruan Dan Ilmu Tarbiyah, 3(1), 77-87.

Coccia, M. (2014). Socio-cultural origins of the 
patterns of technological innovation: What is the likely interaction among religious culture, religious plurality and innovation? Towards a theory of socio-cultural drivers of the patterns of technological innovation. Technology in Society, 36, 1325.

Evans, C. (2008). Religious education in public schools: An international human rights perspective. Human Rights Law Review, 8 (3), 449-473.

Huda, M., Jasmi, K. A., Mustari, M. I. B., \& Basiron, A. B. (2017). Understanding of Wara'(Godliness) as a Feature of Character and Religious Education. The Social Sciences, 12(6), 1106-1111.

Knauth, T., \& Vieregge, D. (2020). Religious Education and Dialogue in Contextual Perspective: A Comparative Case Study in Hamburg and Duisburg (Germany). In Religious Diversity and Interreligious Dialogue (pp. 225-235). Springer, Cham.

Parker, L. (2017). Religious environmental education? The new school curriculum in Indonesia. Environmental Education Research, 23(9), 1249-1272.

Yusuf, M., \& Sterkens, C. J. A. (2015). Analysing the state's laws on religious education in post-New Order Indonesia. 